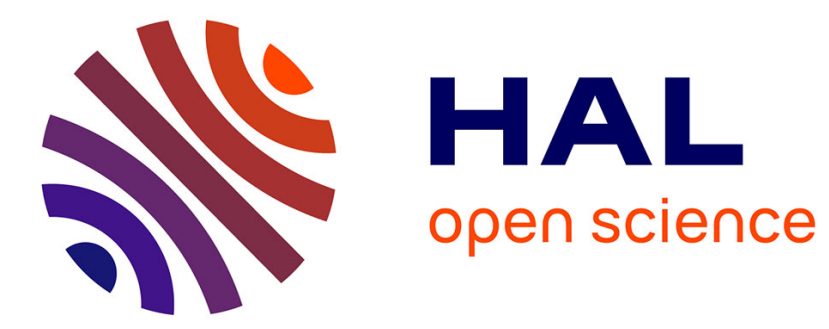

\title{
Market Power in the Expanding Nordic Power Market
} Mikael Bask, Jens Lundgren, Niklas Rudholm

\section{To cite this version:}

Mikael Bask, Jens Lundgren, Niklas Rudholm. Market Power in the Expanding Nordic Power Market. Applied Economics, 2009, pp.1. 10.1080/00036840802600269 . hal-00582266

\section{HAL Id: hal-00582266 https://hal.science/hal-00582266}

Submitted on 1 Apr 2011

HAL is a multi-disciplinary open access archive for the deposit and dissemination of scientific research documents, whether they are published or not. The documents may come from teaching and research institutions in France or abroad, or from public or private research centers.
L'archive ouverte pluridisciplinaire HAL, est destinée au dépôt et à la diffusion de documents scientifiques de niveau recherche, publiés ou non, émanant des établissements d'enseignement et de recherche français ou étrangers, des laboratoires publics ou privés. 


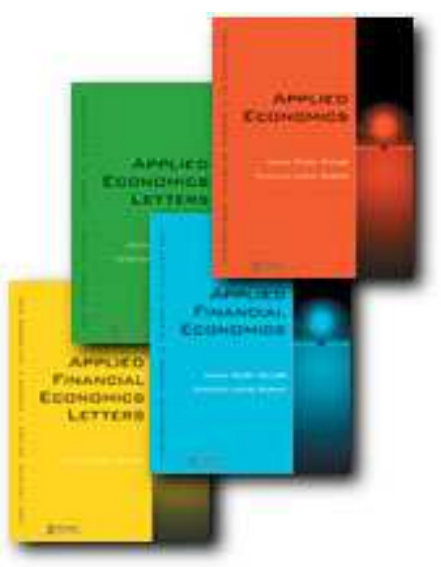

\section{Market Power in the Expanding Nordic Power Market}

\begin{tabular}{|c|c|}
\hline Journal: & Applied Economics \\
\hline Manuscript ID: & APE-07-0549.R1 \\
\hline Journal Selection: & Applied Economics \\
\hline $\begin{array}{r}\text { Date Submitted by the } \\
\text { Author: }\end{array}$ & $31-$ Oct-2008 \\
\hline Complete List of Authors: & $\begin{array}{l}\text { Bask, Mikael; Monetary Policy and Research Department, Bank of } \\
\text { Finland } \\
\text { Lundgren, Jens; Umeå University, Economics } \\
\text { Rudholm, Niklas; Dalarna University, Economics }\end{array}$ \\
\hline JEL Code: & $\begin{array}{l}\text { C32 - Time-Series Models < C3 - Econometric Methods: } \\
\text { Multiple/Simultaneous Equation Models < C - Mathematical and } \\
\text { Quantitative Methods, D43 - Oligopoly and Other Forms of Market } \\
\text { Imperfection < D4 - Market Structure and Pricing < D - } \\
\text { Microeconomics, L13 - Oligopoly and Other Imperfect Markets < L1 } \\
\text { - Market Structure, Firm Strategy, and Market Performance < L - } \\
\text { Industrial Organization }\end{array}$ \\
\hline Keywords: & $\begin{array}{l}\text { Bresnahan-Lau method, conjectural variation elasticity, electricity } \\
\text { market, market power, Nord Pool }\end{array}$ \\
\hline
\end{tabular}

\section{ऽ ScholaroNE" \\ Manuscript Central}




\title{
Market Power in the Expanding Nordic Power Market*
}

\author{
Mikael Bask ${ }^{\dagger}$ \\ Department of Finance and Statistics \\ Swedish School of Economics and Business Administration \\ P.O. Box 479, FIN-00101 Helsinki, Finland \\ Jens Lundgren $\ddagger$ \\ Department of Economics, Umeå University \\ SE-901 87 Umeå, Sweden \\ Niklas Rudholm ${ }^{\S}$ \\ Department of Economics, Dalarna University \\ SE-781 88 Borlänge, Sweden; and \\ The Swedish Retail Institute (HUI) \\ SE-103 29 Stockholm, Sweden
}

October 31, 2008

\begin{abstract}
We examine if the Nordic power market, Nord Pool, has been competitive or if electricity suppliers have had market power. Specifically, since the evolution from national markets to a multi-national and largely deregulated power market has taken place stepwise, we also examine how the degree of market power has evolved during this integration process. The Bresnahan-Lau method together with weekly data during 1996-2004 are used in the analysis, which shows that electricity suppliers have had small, but statistically significant, market power, but that the market power has been reduced as the Nord Pool area has expanded.
\end{abstract}

JEL classification: C32; D43; L13.

Keywords: Bresnahan-Lau Method; Conjectural Variation; Electricity Market; Market Power; Nord Pool.

\footnotetext{
* The authors are grateful to an anonymous referee, Jörgen Hellström, Mark Taylor and seminar participants at Umeå University for helpful comments and suggestions as well as for financial support from the JC Kempe Memorial Foundation and Sparbankernas Forskningsstiftelser. The usual disclaimer applies.

$\dagger$ E-mail: mikael.bask@hanken.fi

‡E-mail: jens.lundgren@econ.umu.se

$\S$ Corresponding author. E-mail: nru@du.se
} 


\section{Introduction}

Denmark, Finland, Norway and Sweden have cooperated during several years to provide their citizens with an efficient and reliable electricity source. In fact, all of them have reformed their electricity sectors and have today access to a common power market consisting of two parts: (i) bilateral trade of contracts between operators; and (ii) the non-mandatory power exchange, Nord Pool.

Because of these reforms, it is natural to ask whether they have been successful: has the common power market been competitive or have electricity suppliers had market power? Moreover, since there was a stepwise evolution from national markets to a multi-national and largely deregulated power market, we also ask how the degree of market power has evolved during this integration process?

A straightforward measure of a market's competitiveness is the price-marginal cost markup since it is zero at a perfectly competitive market, meaning that the electricity price should equal the production cost of the marginal unit of electricity. However, even though market prices are easily accessible in the Nordic power market, this is not the case with marginal costs and some other method must be used to measure the degree of market power. One such method is a conjectural variation method named the Bresnahan [7]-Lau [19] method. ${ }^{1}$

The conjectural variation elasticity at the industry level is the average of the individual firms' conjectural variation elasticities, which measure the firms' output response to the single firm's output change as conjectured by this firm. Thus, if there is perfect competition, there is no output response since a single firm cannot affect output at the industry level, whereas the response is one-toone if there is no competition since the industry behaves as a single firm.

The conjectural variation elasticity is estimated from a two-equation system, where the first equation is electricity demand as a function of electricity price and at least one exogenous variable, whereas the second equation is electricity supply, derived from profit maximization, which is electricity price as a function of industry output, the same exogenous variables as in electricity demand and maybe some other exogenous variables.

The exogenous variables are introduced to solve an identification problem. Bresnahan [7] solved this problem by using a rotation variable in the demand equation, whereas Lau [19] showed that the identification of market power is possible as long as demand is non-separable in at least one exogenous variable. Thus, if at least one exogenous variable is part of an interaction term in the demand equation, the identification problem is solved since the interaction term acts as a rotation variable and it is also non-separable in the exogenous variable. ${ }^{2}$

Hjalmarsson [15] and Vassilopoulos [24] are the only studies that we are aware of that measure the degree of market power in the Nord Pool area, and they find that the power market has been competitive. However, none of them studies the effect of market expansion on the degree of market power, meaning that the present paper fills a gap in the literature.

\footnotetext{
${ }^{1}$ Examples of studies that use this method, or some variant of it, include Aiginger et al [1], Alexander [2], Azzam and Park [6], Böckem [8], Hyde and Perloff [16], and Shaffer [21].

2 The Bresnahan-Lau method has been criticized by Corts [10], who shows that the estimated conjectural variation elasticity measures the marginal, and not the average, collusive behavior in an industry. However, by using direct measures of marginal costs to calculate the 'true' value of the conduct parameter, Clay and Troesken [9] and Genesove and Mullin [13] show that the method preforms well when the degree of market power is not too high. Thus, since Nord Pool consists of over 100 firms, the method is appropriate to use.
} 
The rest of this paper is outlined as follows: The Bresnahan-Lau method or model is presented in Section 2, Section 3 contains the empirical analysis, and Section 4 concludes the paper with a discussion.

\section{The Bresnahan-Lau model}

\subsection{The static model}

The Bresnahan-Lau model is a static model since there are no lagged or lead values of the variables included. Specifically, the electricity demand function is

$$
Q=D(P, Z ; \alpha)+\varepsilon,
$$

where $Q$ is quantity demanded, $P$ is price of power, $Z$ is a vector of exogenous variables, $\alpha$ is a vector of parameters to be estimated, and $\varepsilon$ is a random term. Moreover, the electricity supply relation is

$$
P=c(Q, W ; \beta)-\lambda h(Q, Z ; \alpha)+\eta,
$$

where $W$ is a vector of exogenous variables, $\beta$ is a vector of parameters to be estimated, $\lambda$ is the degree of market power, and $\eta$ is a random term.

$c(\cdot)$ in $(2)$ is the marginal cost of producing electricity, meaning that when $\lambda=0$, the price of power is equal to the marginal cost and we have a perfectly competitive power market since all suppliers of electricity are price-takers. However, when suppliers are price-setters, the marginal revenue as perceived by the single supplier is equal to the marginal cost, and this is because $P+h(\cdot)$ is the marginal revenue at the industry level and $\lambda$ is the perceived percentage of this revenue. Thus, when $\lambda=1$, we have a perfect cartel in the power market.

Then, by assuming a linear demand function for electricity,

$$
Q=\alpha_{0}+\alpha_{P} P+\alpha_{Z} Z+\alpha_{P Z} P Z+\varepsilon,
$$

including an interaction term between $P$ and $Z$ that acts as a rotation variable, and a linear marginal cost function,

$$
c(\cdot)=\beta_{0}+\beta_{Q} Q+\beta_{W} W,
$$

the electricity supply relation is

$$
P=\beta_{0}+\beta_{Q} Q+\beta_{W} W-\lambda \cdot \underbrace{\left(\frac{Q}{\alpha_{P}+\alpha_{P Z} Z}\right)}_{=Q^{*}}+\eta .
$$

Thus, if we first estimate (3), meaning that we can calculate $Q^{*}$, we can identify the degree of market power, $\lambda$, after having estimated (5).

\subsection{The dynamic model}

Steen and Salvanes [23] argue that a dynamic reformulation of the BresnahanLau model into an error-correcting framework is necessary for two reasons. The first reason is that this framework allows for short-run deviations from long-run 
equilibrium in data, and the second reason is that this framework solves the inference problem when using non-stationary data.

Start by writing the electricity demand function as an autoregressive distributed lag model:

$$
\begin{aligned}
Q_{t}= & \alpha_{P, 0} P_{t}+\alpha_{P, 1} P_{t-1}+\alpha_{Z, 0} Z_{t}+\alpha_{Z, 1} Z_{t-1}+ \\
& \alpha_{P Z, 0} P Z_{t}+\alpha_{P Z, 1} P Z_{t-1}+\alpha_{Q, 1} Q_{t-1}+\varepsilon_{t},
\end{aligned}
$$

and continue by writing the electricity supply relation as an autoregressive distributed lag model:

$$
\begin{aligned}
P_{t}= & \beta_{Q, 0} Q_{t}+\beta_{Q, 1} Q_{t-1}+\beta_{W, 0} W_{t}+\beta_{W, 1} W_{t-1}+ \\
& \lambda_{0} Q_{t}^{*}+\lambda_{1} Q_{t-1}^{*}+\beta_{P, 1} P_{t-1}+\eta_{t},
\end{aligned}
$$

where the long-run stationary equilibrium is found by setting $Q_{t}=Q_{t-1}, P_{t}=$ $P_{t-1}, Z_{t}=Z_{t-1}, P Z_{t}=P Z_{t-1}, W_{t}=W_{t-1}$ and $Q_{t}^{*}=Q_{t-1}^{*}$. Thereafter, if we relax the restriction of one lag and include an intercept term, (6)-(7) can be written in error-correcting forms:

$$
\begin{aligned}
\Delta Q_{t}= & \alpha_{0}+\sum_{i=1}^{k-1} \alpha_{Q, i} \Delta Q_{t-i}+\sum_{i=0}^{k-1} \alpha_{P, i} \Delta P_{t-i}+ \\
& \sum_{i=0}^{k-1} \alpha_{Z, i} \Delta Z_{t-i}+\sum_{i=0}^{k-1} \alpha_{P Z, i} \Delta P Z_{t-i}+ \\
& \gamma^{*}\left(Q_{t-k}-\frac{\alpha_{P}^{*}}{\gamma^{*}} \cdot P_{t-k}-\frac{\alpha_{Z}^{*}}{\gamma^{*}} \cdot Z_{t-k}-\frac{\alpha_{P Z}^{*}}{\gamma^{*}} \cdot P Z_{t-k}\right)+\varepsilon_{t},
\end{aligned}
$$

and

$$
\begin{aligned}
\Delta P_{t}= & \beta_{0}+\sum_{i=1}^{k-1} \beta_{P, i} \Delta P_{t-i}+\sum_{i=0}^{k-1} \beta_{Q, i} \Delta Q_{t-i}+ \\
& \sum_{i=0}^{k-1} \beta_{W, i} \Delta W_{t-i}+\sum_{i=0}^{k-1} \lambda_{i} \Delta Q_{t-i}^{*}+ \\
& \psi^{*}\left(P_{t-k}-\frac{\beta_{Q}^{*}}{\psi^{*}} \cdot Q_{t-k}-\frac{\beta_{W}^{*}}{\psi^{*}} \cdot W_{t-k}-\frac{\lambda^{*}}{\psi^{*}} \cdot Q_{t-k}^{*}\right)+\eta_{t} .
\end{aligned}
$$

See Steen and Salvanes [23] for a derivation and a discussion of the relationship between the distributed lag model and its error-correcting form.

\title{
3 Empirical analysis
}

\subsection{Data set}

The data set consists of weekly data from all Nord Pool participants, covering the period from week 1 in 1996 to week 16 in 2004. See Table 1 for the dates in the integration process, and Table 2 for the variables used, their definitions and data sources.

\author{
[Tables 1-2 about here.]
}


The price variable is Nord Pool's spot price at the system level $(P)$. Further, since the industry sector is the largest consumer of electricity, we include industrial production (Prod) when studying electricity demand. A problem, however, is that data are available only on a monthly basis, whereas all other variables are available on a weekly basis. There are two options at hand: (i) to exclude this variable (Vassilopoulos [24]); or (ii) to interpolate data into weekly estimates (Hjalmarsson [15]). We choose to interpolate since the variation of this important variable within each month is expected to be small.

Two other variables affecting electricity demand are the temperature (Temp), which is a proxy for the amount of electricity needed for heating, and the length of a day (Daylength), which is a proxy for the amount of electricity needed for lightning. We also need at least one interaction variable to be able to identify the degree of market power. For this reason, we let the spot price at the system level to interact with the temperature as well as the length of a day in the Nord Pool area $\left(P^{*}\right.$ Temp and $P^{*}$ Daylength $)$.

To determine electricity supply, we need to approximate the marginal cost function and also find variables that shift this function. For this reason, we look at the opportunity cost of hydro generation, and two factors that affect this cost are inflow of water to reservoirs (Inflow) and how full they already are. We choose the inflow variable as a shift variable.

The Nordic power market consists of a relatively large amount of hydro generation, which is a cheap electricity source and has almost no variable costs (Andersson and Bergman [5]), meaning that hydro power is a base load electricity. When more energy is needed, more expensive sources such as thermal power are used, and this residual electricity is produced with a number of inputs such as bio fuel, coal, gas, and oil.

Contrary to hydro power, the technology of residual electricity has higher and more variable costs (Green and Newbery [14]). Therefore, we incorporate the coal price $(\mathrm{Coal})$ and the Brent crude oil price ( $\mathrm{Oil})$ into electricity supply to account for the thermal part of electricity generation. Moreover, to account for the residual electricity trend, we include residual electricity in relation to total electricity production (Resel) as a variable in the analysis.

Finally, the increase in electricity traded at Nord Pool's spot market is an exogenous trend that need to be taken into consideration when building the empirical model. Following Hjalmarsson [15], this is accomplished by regressing the system turnover (Turnover) on the market share (Market share) and, thereafter, use the residual as a detrended quantity variable $(Q)$.

See Table 3 for descriptive statistics of the variables used in the empirical analysis in the different subperiods in the integration process.

[Table 3 about here.]

\subsection{Statistical tests}

Before specifying the two-equation regression model, we need to test if the variables are stationary. If this is not the case, we also need to test for cointegration to ensure the existence of a long-run equilibrium in data. Finally, a separability test is preformed on the interaction variables to make sure that the degree of market power is identifiable (Lao [19]). 
Dickey-Fuller's augmented unit root test is used in companion with the AIC to test if the variables are stationary. However, a potential problem is that the variables are highly seasonal, meaning that we have to deseasonalize data before using the test. This is accomplished by introducing weekly dummy variables and estimate the following equation:

$$
y_{t}=\alpha_{0}+\sum_{i=2}^{52} \alpha_{i} W e e k_{i}+\hat{y}_{t}
$$

where $\hat{y}_{t}$ is the regression residual, which is the deseasonalized value of $y_{t}$. See Table A.1 in the Appendix for results.

Thereafter, we use the Johansen [18] approach to search for cointegrated relations between the variables. Specifically, we use the Johansen and Juselius [17] multivariate cointegration test, which is a maximum likelihood test on the results from a vector autoregression. As above, a potential problem is that the variables are highly seasonal, meaning that deseasonalized data are used in the tests. See Tables A.2-A.3 in the Appendix for results, which show that we have cointegrated relationships among the integrated variables, both at the demand and supply sides of the power market.

Finally, electricity demand must be non-separable in at least one of the interaction variables, and the appropriate test is an extension of the cointegration test by introducing restrictions that the interaction variables are zero. The restricted model is, thereafter, compared to the unrestricted model using a likelihood ratio test. See Table A.2 in the Appendix for results, which show that the interaction variables should be included in the regression model.

\subsection{Estimation results}

The demand function and the supply relation for electricity are

$$
\begin{aligned}
Q_{t j}= & \alpha_{0}+\sum_{i=1}^{k} \alpha_{Q, i} Q_{t-i}+\sum_{i=0}^{k} \alpha_{\text {Prod }, i \text { Prod }_{t-i}+}+ \\
& \sum_{i=0}^{k} \alpha_{T e m p, i} \text { Temp }_{t-i}+\sum_{i=0}^{k} \alpha_{\text {Daylength }, i} \text { Daylengt }_{t-i}+ \\
& \sum_{j=1}^{l} \sum_{i=0}^{k} \alpha_{C V_{j}, i} C V_{j, t-1}+\varepsilon_{t},
\end{aligned}
$$

and

$$
\begin{aligned}
\triangle P_{t m j}= & \beta_{0}+\sum_{m=1}^{q} \sum_{i=1}^{k} \beta_{P_{m}, i} \triangle P_{m, t-i}+\sum_{i=0}^{k} \beta_{Q, i} Q_{t-i}+ \\
& \sum_{i=0}^{k} \beta_{Q^{2}, i} Q_{t-i}^{2}+\sum_{i=0}^{k} \lambda_{i} Q_{t-i}^{*}+\sum_{i=0}^{k} \beta_{\text {Inflow }, \text { Inflow }}+i+ \\
& \sum_{i=0}^{k} \beta_{\text {Coal }, i} \text { Coal }_{t-1}+\sum_{i=0}^{k} \beta_{\text {Oil }, i} \text { Oil }_{t-1}+ \\
& \sum_{i=0}^{k} \beta_{\text {Resel }, i_{i} \text { Resel }_{t-i}}+\sum_{j=1}^{l} \gamma_{C V_{j}} C V_{t-1}+\eta_{t}
\end{aligned}
$$


where $\{C V\}_{j=1}^{l}$ are cointegrated vectors. Because of a simultaneity problem that arises in demand and supply models, two-stage least squares is used in the analysis. In (11), the first lag of the system price, the temperature, and the inflow of water to reservoirs are used as instruments, and in (12), the temperature and the length of a day are used as instruments. Both equations are estimated using autocorrelation and heteroscedasticity consistent standard errors.

First, (11) is estimated for the whole period using five lags. Insignificant variables are, thereafter, removed from the regression equation and a parsimonious model is derived. See Table A.4 in the Appendix for results for the whole period and for each subperiod in the integration process, which show that lagged quantities have a positive impact on electricity demand. The estimates for the cointegrating vectors show that the current price has a negative impact on electricity demand. Moreover, increased temperature and longer days cause electricity demand to fall.

Second, (12) is estimated including $Q^{*}=\frac{Q}{\delta Q / \delta P}$ in the regression equation. Since the price variables are non-stationary, an error-correction model is used to estimate electricity supply, and as the error-correction term, we use the first lag of the cointegrating vector. Electricity supply is estimated for the whole period, and a parsimonious model is derived as above, which is estimated for each subperiod in the integration process. See Table A.5 in the Appendix for results, which show that the inflow of water to reservoirs has a negative impact on electricity price, while the use of residual electricity has a positive impact on this price. The error-correction term indicates a slow error-correction in line with previous literature (Hjalmarsson [15] and Vassilopoulos [24]).

Finally, estimates of the degree of market power, $\lambda$, are found in Table $4 .^{3}$

[Table 4 about here.]

The results show that electricity suppliers have had a small, but statistically significant, degree of market power during the whole period, even though it has been reduced as the market has expanded. In the last subperiod, there was no market power in the Nordic power market. In economic terms, the estimated market powers indicate small markups over marginal costs. In fact, the implied Lerner index gives a markup of less than one percent in the different subperiods and an even smaller markup for the whole period. ${ }^{4}$

\section{Discussion}

The aim of this paper has been to examine how the degree of market power has changed as the Nordic power market has evolved from national markets to a multi-national market. While previous studies have not found any evidence of market power in the Nord Pool area (Hjalmarsson [15] and Vassilopoulos [24]), our study, which use a more comprehensive data set, indicate that there has been a small, but statistically significant, degree of market power during almost the whole period. More importantly, our results show that the degree of market power has been reduced as the market has expanded.

\footnotetext{
${ }^{3} \lambda \in[0,1]$ in Table 4 . However, since no minus sign is included in the regression equation, $\lambda$ changes sign. Therefore, in Table A.5, $\lambda \in[-1,0]$.

${ }^{4}$ The implied Lerner index is defined as $\frac{P-M C}{P}=-\frac{\lambda}{\varepsilon}$, where $\varepsilon$ is the demand elasticity (Steen [22]).
} 
However, the implied Lerner index gives a markup of less than one percent over marginal cost, meaning that the impact of market power on the electricity price has not been that severe. Steen [22] examined the Norwegian market with results similar to ours and concluded that "the results are probably more a word of warning that we should be careful to allow more concentration in this market". Most likely, there are several reasons why the markup has been low, one of them being the threat of entry.

Wolfram [25] argues that there are two reasons why firms in the UK have not utilized all potential market power: (i) the threat of market interventions from the authorities; and (ii) the threat of entry into the market. Although her results may not be directly transferable to the Nordic power market, Edin [11] argues that it is possible that the threat of entry has kept the price close to marginal cost also in the Nordic market.

Moreover, Amundsen and Bergman [3] analyze the effect of cross-ownerships in the electricity market and how mergers will affect this market. They conclude that mergers and cross-ownerships may re-establish at least part of the market power that the deregulation has removed.

Finally, Amundsen and Bergman [4] compare the Nordic power market to the Californian power market and find that the Nordic market has worked well. This is because the Nordic market is characterized by a simple but sound market design, successful dilution of market power, strong political support for a market-based electricity system, and voluntary informal commitment to public service by the power industry.

\section{References}

[1] Aiginger, K., Brandner, P. and Wüger, M. (1995). Measuring market power for some industrial sectors in Austria. Applied Economics, 27, 369-376.

[2] Alexander, D.L. (1988). An empirical test of monopoly behaviour: An application to the Hardwood case. Applied Economics, 20, 1115-1127.

[3] Amundsen, E.S. and Bergman, L. (2002). Will cross-ownership re-establish market power in the Nordic power market? Energy Journal, 23 (2), 73-95.

[4] Amundsen, E.S. and Bergman, L. (2006). Why has the Nordic electricity market worked so well? Utilities Policy, 14, 148-157.

[5] Andersson, B. and Bergman, L. (1995). Market structure and the price of electricity: An ex ante analysis of deregulated Swedish markets. Energy Journal, 16 (2), 97-109.

[6] Azzam, A. and Park, T. (1993). Testing for switching market conduct. Applied Economics, 25, 795-800.

[7] Bresnahan, T.F. (1982). The oligopoly solution concept is identified. Economics Letters, 10, 87-92.

[8] Böckem, S. (2004). Cartel formation and oligopoly structure: A new assessment of the crude oil market. Applied Economics, 36, 1355-1369. 
[9] Clay, K. and Troesken, W. (2003). Further tests of static oligopoly models: Whiskey, 1882-1898. Journal of Industrial Economics, 51, 151-166.

[10] Corts, K.S. (1999). Conduct parameters and the measurement of market power. Journal of Econometrics, 88, 227-250.

[11] Edin, K.-A. (2006). Marknadsmakt i vattenkraft-värmekraftsystem. Elforsk rapport 06:87.

[12] Fuller, W.A. (1976). Introduction to statistical time series. New York: John Wiley and Sons.

[13] Genesove, D. and Mullin, W.P. (1998). Testing static oligopoly models: Conduct and cost in the sugar industry, 1890-1914. RAND Journal of Economics, 29, 355-377.

[14] Green, R.J. and Newbery, D.M. (1992). Competition in the British electricity spot market. Journal of Political Economy, 100, 929-953.

[15] Hjalmarsson, E. (2000). Nord Pool: A power market without market power. Discussion Paper No. 28, Göteborg University.

[16] Hyde, C.E. and Perloff, J.M. (1998). Multimarket market power estimation: The Australian retail meat sector. Applied Economics, 30, 1169-1176.

[17] Johansen, S. and Juselius, K. (1990). Maximum likelihood estimation and inference on cointegration: With applications to the demand for money. Oxford Bulletin of Economics and Statistics, 52, 169-210.

[18] Johansen, S. (1988). Statistical analysis of cointegration vectors. Journal of Economic Dynamics and Control, 12, 231-254.

[19] Lau, L.J. (1982). On identifying the degree of competitiveness from industry price and output data. Economics Letters, 10, 93-99.

[20] Osterwald-Lenum, M. (1992). A note with quantiles of the asymptotic distribution of the maximum likelihood cointegration rank test statistics. $O x$ ford Bulletin of Economics and Statistics, 54, 461-472.

[21] Shaffer, S. (2002). Ownership structure and market conduct among Swiss banks. Applied Economics, 34, 1999-2009.

[22] Steen, F. (2003). Do bottlenecks generate market power? An empirical study of the Norwegian electricity market. Discussion Paper No. 26, Norwegian School of Economics and Business Administration.

[23] Steen, F. and Salvanes, K.G. (1999). Testing for market power using a dynamic oligopoly model. International Journal of Industrial Organization, 17, $147-177$.

[24] Vassilopoulos, P. (2003). Models for the identification of market power in wholesale electricity markets. Discussion Paper, University of ParisDauphine.

[25] Wolfram, C.D. (1999). Measuring duopoly power in the British electricity spot market. American Economic Review, 89, 805-826. 
Table 1: Integration process at the Nordic power market

\begin{tabular}{lll}
\hline \hline Country & Date for affiliation & Date for complete integration \\
& & \\
Norway & January 1, 1993 & January 1, 1993 \\
Sweden & January 1, 1996 & January 1, 1996 \\
Finland & December 29, 1997 & March 1, 1999 \\
Western Denmark & July 1, 1999 & March 1, 2002 \\
Eastern Denmark & October 1, 2000 & March 1, 2002 \\
\hline \hline
\end{tabular}

Table 2: Variables, definitions and data sources

\begin{tabular}{|c|c|}
\hline$\overline{\text { Variable }}$ & Definition and data source \\
\hline$P$ & $\begin{array}{l}\text { Nord Pool's spot price at the system level, NOK/MWh. } \\
\text { Source: Nord Pool ASA }\end{array}$ \\
\hline Prod & $\begin{array}{l}\text { Weighted average of the countries' industrial production } \\
\text { indexes using the countries' GDP shares as weights. } \\
\text { Sources: Statistics Denmark, Statistics Finland, Statistics Norway, } \\
\text { Statistics Sweden and OECD }\end{array}$ \\
\hline Temp & $\begin{array}{l}\text { Weighted average of the participating countries average } \\
\text { temperatures, where the weights are the countries' GDP } \\
\text { shares, and the participating countries' average temperatures, } \\
\text { in turn, are weighted averages of the average temperatures } \\
\text { in selected cities, where the weights are the cities' } \\
\text { populations. } .^{a} \text { Sources: Nord Pool ASA and SMHI }\end{array}$ \\
\hline Daylength & $\begin{array}{l}\text { Number of hours the sun is above the horizon in Gothenburg, } \\
\text { Sweden. Source: www.stjarnhimlen.se }\end{array}$ \\
\hline Inflow & $\begin{array}{l}\text { Inflow to water reservoirs, recalculated from water inflow to } \\
\text { the water's energy content in MWh. } \\
\text { Sources: Nord Pool ASA and SYKE }\end{array}$ \\
\hline Coal & $\begin{array}{l}\text { Price of coal used to generate electricity, USD/MWh. } \\
\text { Source: The McCloskey Group }\end{array}$ \\
\hline Oil & $\begin{array}{l}\text { Price of Brent crude oil used to generate electricity, } \\
\text { USD/MWh. }\end{array}$ \\
\hline Resel & $\begin{array}{l}\text { Source: tonto.eia.doe.gov/oog/ftparea/wogirs/xls/psw14.xls } \\
\text { Residual electricity traded at Nord Pool's spot market in } \\
\text { relation to total electricity production. Source: Nord Pool ASA }\end{array}$ \\
\hline Turnover & $\begin{array}{l}\text { Number of MWh traded at Nord Pool's spot market. } \\
\text { Source: Nord Pool ASA }\end{array}$ \\
\hline Market share & $\begin{array}{l}\text { The market share of Nord Pool's spot market measured as } \\
\text { the turnover at the spot market in relation to total electricity } \\
\text { production. Source: Nord Pool ASA }\end{array}$ \\
\hline$Q$ & $\begin{array}{l}\text { Detrended turnover at Nord Pool's spot market measured by } \\
\text { regressing the turnover at the spot market on its market } \\
\text { share, where the residuals are used as detrended turnover. } \\
\text { Source: Nord Pool ASA }\end{array}$ \\
\hline
\end{tabular}

Note: ${ }^{a}$ The cities in Denmark are Copenhagen and Billund; the cities in Finland are Helsinki and Ivalo; the cities in Norway are Oslo, Bergen, Trondheim and Troms $\varnothing$; and the cities in Sweden are Stockholm, Gothenburg, Luleå and Östersund. 
Table 3: Descriptive statistics

\begin{tabular}{|c|c|c|c|c|}
\hline Variable & $9601-0416$ & $9601-9908$ & $9909-0209$ & $0210-0416$ \\
\hline \multirow[t]{2}{*}{$P$} & 178.17 & 181.06 & 135.08 & 234.85 \\
\hline & (85.45) & (79.09) & $(44.50)$ & (103.07) \\
\hline \multirow[t]{2}{*}{ Prod } & 96.21 & 90.96 & 98.51 & 100.72 \\
\hline & (8.09) & (6.68) & (7.48) & (6.46) \\
\hline \multirow[t]{2}{*}{ Temp } & 6.83 & 5.95 & 7.61 & 7.05 \\
\hline & $(7.46)$ & $(7.56)$ & (6.96) & (7.91) \\
\hline \multirow[t]{2}{*}{ Daylength } & 86.06 & 85.25 & 86.41 & 86.76 \\
\hline & $(26.99)$ & $(27.23)$ & $(27.23)$ & $(26.51)$ \\
\hline \multirow[t]{2}{*}{ Inflow } & $3.66 E+06$ & $3.43 E+06$ & $4.24 E+06$ & $3.20 E+06$ \\
\hline & $(2.98 E+06)$ & $(2.92 E+06)$ & $(3.02 E+06)$ & $(2.92 E+06)$ \\
\hline \multirow[t]{2}{*}{ Coal } & 37.91 & 39.93 & 34.73 & 39.43 \\
\hline & $(8.17)$ & (5.60) & $(4.40)$ & (12.85) \\
\hline \multirow[t]{2}{*}{ Oil } & 90.31 & 74.55 & 95.44 & 106.35 \\
\hline & $(21.85)$ & (18.70) & $(20.25)$ & (10.23) \\
\hline \multirow[t]{2}{*}{ Resel } & 0.11 & 0.08 & 0.11 & 0.16 \\
\hline & $(0.05)$ & $(0.04)$ & $(0.02)$ & $(0.04)$ \\
\hline \multirow[t]{2}{*}{ Turnover } & $1.66 E+06$ & $9.31 E+05$ & $1.86 E+06$ & $2.43 E+06$ \\
\hline & $(7.43 E+05)$ & $(2.44 E+05)$ & $(4.56 E+05)$ & $(5.73 E+05)$ \\
\hline \multirow[t]{2}{*}{ Market share } & 0.25 & 0.17 & 0.26 & 0.34 \\
\hline & $(0.07)$ & $(0.03)$ & $(0.03)$ & $(0.04)$ \\
\hline \multirow[t]{2}{*}{$Q$} & 0.00 & $-3.63 E+05$ & $8.37 E+05$ & $-6.47 E+05$ \\
\hline & $(3.22 E+05)$ & $(2.79 E+05)$ & $(3.25 E+05)$ & $(3.52 E+05)$ \\
\hline \multirow[t]{2}{*}{$P^{*}$ Temp } & $1.00 E+04$ & 984.86 & 901.88 & $1.16 E+04$ \\
\hline & $(1.49 E+04)$ & $(1.62 E+04)$ & $(985.65)$ & $(1.85 E+04)$ \\
\hline \multirow[t]{2}{*}{$P^{*}$ Daylength } & $1.46 E+05$ & $1.51 E+05$ & $1.13 E+05$ & $1.86 E+05$ \\
\hline & $(7.25 E+04)$ & $(8.63 E+04)$ & $(4.82 E+04)$ & $(5.44 E+04)$ \\
\hline $\begin{array}{l}\text { Number of } \\
\text { observations }\end{array}$ & 432 & 164 & 157 & 111 \\
\hline
\end{tabular}

Note: $9601-0416$ refers to the period week 1,1996 , to week 16,2004 , etc.

Table 4: Degree of market power

\begin{tabular}{lcccc}
\hline \hline Variable & $9601-0416$ & $9601-9908$ & $9909-0209$ & $0210-0416$ \\
$Q^{*}$ & $6.97 E-05^{*}$ & $5.56 E-04^{* *}$ & $2.02 E-04^{*}$ & $-7.58 E-04$ \\
& $(1.47 E-05)$ & $(2.38 E-04)$ & $(5.26 E-05)$ & $(2.06 E-03)$ \\
\hline \hline
\end{tabular}

Note: $9601-0416$ refers to the period week 1,1996, to week 16,2004 , etc. ${ }^{*}$ Significant at the $1 \%$ level, ** significant at the $5 \%$ level. 


\section{Appendix}

\begin{tabular}{c} 
Table A.1: Augmented Dickey-Fuller unit root tests \\
\hline \hline Variable \\
$I(0) \quad$ Lags
\end{tabular}

\begin{tabular}{lrrrr} 
Table A.1: Augmented Dickey-Fuller unit root test \\
\hline \hline Variable & $I(0)$ & Lags & $I(1)$ & Lags \\
& & & & \\
$P$ & -2.73 & 7 & $-9.10^{*}$ & 6 \\
Prod & -2.94 & 9 & $-11.82^{*}$ & 8 \\
Temp & $-6.05^{*}$ & 7 & - & - \\
Inflow & $-7.50^{*}$ & 2 & - & - \\
Coal & -1.85 & 14 & $-3.49^{*}$ & 13 \\
Oil & 0.24 & 6 & $-10.57^{*}$ & 5 \\
Resel & -3.20 & 5 & $-9.13^{*}$ & 4 \\
$Q$ & $-3.21^{*}$ & 8 & - & - \\
$P^{*}$ Temp & -4.18 & 9 & - & - \\
$P^{*}$ Daylength & -2.45 & 3 & $-11.82^{*}$ & 2 \\
\hline \hline
\end{tabular}

Note: * Significant at the $1 \%$ level. The critical values are from Fuller [12].

Table A.2: Multivariate cointegration test of the demand function

\begin{tabular}{|c|c|c|}
\hline & Demand function $^{b}$ & $95 \%$ critical value \\
\hline $\begin{array}{l}0 \text { cointegration vector } \\
r=0\end{array}$ & $71.69^{*}$ & 29.70 \\
\hline $\begin{array}{l}1 \text { cointegration vectors } \\
r \leq 1\end{array}$ & $30.04^{*}$ & 15.40 \\
\hline $\begin{array}{l}2 \text { cointegration vectors } \\
r \leq 2\end{array}$ & $5.93^{* *}$ & 3.76 \\
\hline \multicolumn{3}{|l|}{ Standardized eigenvectors } \\
\hline Variable & Prod & $P^{*}$ Daylength \\
\hline$C V 1$ & 1.00 & -0.01 \\
\hline$C V^{2}$ & 853.46 & 0 \\
\hline \multicolumn{3}{|l|}{ Separability tests } \\
\hline$H_{0}: \beta_{1, P}=\beta_{2, P}=0$ & $28.17^{*}$ & \\
\hline$H_{0}: \beta_{2, \operatorname{Prod}}=0$ & $30.18^{*}$ & \\
\hline$H_{0}: \beta_{1, P * \text { Daylength }}=0$ & $26.32^{*}$ & \\
\hline
\end{tabular}

Note: ${ }^{b} \mathrm{k}=4$ number of lags, $\mathrm{n}=428$ number of observations. $*$ Significant at the $1 \%$ level, ** significant at the $5 \%$ level, ${ }^{* * *}$ significant at the $10 \%$ level. The critical values are from Osterwald-Lenum [20]. 
Table A.3: Multivariate cointegration test of the supply relation

0 cointegration vector $31.30^{* *}$

29.70

$r=0$

1 cointegration vectors $16.23^{* *}$ $r \leq 1$

2 cointegration vectors

$6.21^{* *}$

$r \leq 2$

Standardized eigenvectors

Variable

Oil

Resel

CV1

$1.00 \quad-1.69$

$-110.93$

$C V^{2}$
15.40

3.76

Note: ${ }^{c} \mathrm{k}=2$ number of lags, $\mathrm{n}=430$ number of observations. ${ }^{*}$ Significant at the $1 \%$ level, ** significant at the $5 \%$ level. The critical values are from Osterwald-Lenum [20]. 
Table A.4: Estimation results of the demand function

\begin{tabular}{|c|c|c|c|c|}
\hline Variable & $9601-0416$ & $9601-9908$ & $9909-0209$ & $0210-0416$ \\
\hline Constant & $\begin{array}{c}4.60 E+05^{*} \\
(9.41 E+05)\end{array}$ & $\begin{array}{c}3.43 E+05^{*} \\
(1.28 E+05)\end{array}$ & $\begin{array}{c}7.25 E+05^{*} \\
(1.53 E+05)\end{array}$ & $\begin{array}{l}4.95 E+05^{* *} \\
(2.36 E+05)\end{array}$ \\
\hline$Q(-1)$ & $\begin{array}{r}0.78^{*} \\
(0.04)\end{array}$ & $\begin{array}{r}0.90^{*} \\
(0.03)\end{array}$ & $\begin{array}{c}0.52^{*} \\
(0.05)\end{array}$ & $\begin{array}{r}0.67^{*} \\
(0.11)\end{array}$ \\
\hline Temp & $\begin{array}{r}-4.65 E+04^{* *} \\
(1.85 E+04)\end{array}$ & $\begin{array}{r}-962.25 \\
(1.41 E+04)\end{array}$ & $\begin{array}{r}-1.17 E+05^{*} \\
(2.51 E+04)\end{array}$ & $\begin{array}{l}-5.29 E+04 \\
(4.09 E+04)\end{array}$ \\
\hline Daylength & $\begin{array}{r}-3.21 E+04^{*} \\
(495.68)\end{array}$ & $\begin{array}{r}-1.58 E+04^{*} \\
(443.86)\end{array}$ & $\begin{array}{r}-4.97 E+04^{*} \\
(788.63)\end{array}$ & $\begin{array}{r}-4.67 E+04^{*} \\
(1.21 E+04)\end{array}$ \\
\hline$C V 1$ & $\begin{array}{r}-712.57^{*} \\
(189.48)\end{array}$ & $\begin{array}{r}-291.97^{* * *} \\
(174.23)\end{array}$ & $\begin{array}{r}-1.01 E+04^{* *} \\
(417.72)\end{array}$ & $\begin{array}{r}-889.17^{*} \\
(188.69)\end{array}$ \\
\hline CV2 & $\begin{array}{r}-151.34^{* *} \\
(73.48)\end{array}$ & $\begin{array}{r}-208.56^{* *} \\
(100.24)\end{array}$ & $\begin{array}{r}-211.05^{* *} \\
(103.96)\end{array}$ & $\begin{array}{r}-46.80 \\
(183.89)\end{array}$ \\
\hline$R^{2}$ & 0.91 & 0.96 & 0.95 & 0.81 \\
\hline \multicolumn{5}{|c|}{ Long-run parameters } \\
\hline Constant & $\begin{array}{r}2.10 E+06^{*} \\
(5.24 E+05)\end{array}$ & & & \\
\hline Temp & $\begin{array}{r}-2.12 E+05^{*} \\
(6.53 E+04)\end{array}$ & & & \\
\hline Daylength & $\begin{array}{r}-1.46 E+05^{*} \\
(3.40 E+04)\end{array}$ & & & \\
\hline$C V 1$ & $\begin{array}{r}-3.25 E+04^{*} \\
(1.20 E+04)\end{array}$ & & & \\
\hline$C V^{2}$ & $\begin{array}{r}-689.73^{* *} \\
(352.57)\end{array}$ & & & \\
\hline \multicolumn{5}{|c|}{ Estimates of the individual components in $C V 1$ and $C V 2$} \\
\hline$P 1$ & $-3.25 E+04$ & & & \\
\hline$P^{2}$ & -689.73 & & & \\
\hline$P D$ & 325.00 & & & \\
\hline Prod & $-5.89 E+05$ & & 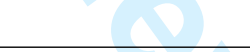 & \\
\hline
\end{tabular}

Note: $9601-0416$ refers to the period week 1, 1996, to week 16,2004 , etc. * Significant at the $1 \%$ level, ${ }^{* *}$ significant at the $5 \%$ level, ${ }^{* * *}$ significant at the $10 \%$ level. 
Table A.5: Estimation results of the supply relation

\begin{tabular}{|c|c|c|c|c|}
\hline$\overline{\text { Variable }}$ & $9601-0416$ & $9601-9908$ & $9909-0209$ & "0210-0416 \\
\hline Constant & $\begin{array}{c}4.12^{*} \\
(1.48)\end{array}$ & $\begin{array}{r}4.89^{* * *} \\
(2.56)\end{array}$ & $\begin{array}{r}1.08 \\
(2.13)\end{array}$ & $\begin{array}{r}5.01 \\
(3.99)\end{array}$ \\
\hline$\Delta Q$ & $\begin{array}{r}4.75 E-05^{* * *} \\
(2.49 E-05)\end{array}$ & $\begin{array}{r}1.99 E-05 \\
(2.93 E-05)\end{array}$ & $\begin{array}{r}3.02 E-05 \\
(2.57 E-05)\end{array}$ & $\begin{array}{l}1.96 E-04^{* *} \\
(1.01 E-04)\end{array}$ \\
\hline$Q^{*}$ & $\begin{array}{r}-6.97 E-05^{*} \\
(1.47 E-05)\end{array}$ & $\begin{array}{r}-5.56 E-04^{* *} \\
(2.38 E-04)\end{array}$ & $\begin{array}{r}-2.02 E-04^{*} \\
(5.26 E-05)\end{array}$ & $\begin{array}{r}7.58 E-04 \\
(0.00)\end{array}$ \\
\hline Inflow & $\begin{array}{r}-9.28 E-07^{*} \\
(3.11 E-07)\end{array}$ & $\begin{array}{r}-1.04 E-06^{* *} \\
(4.53 E-07)\end{array}$ & $\begin{array}{r}-8.99 E-07^{* *} \\
(4.44 E-07)\end{array}$ & $\begin{array}{l}-2.08 E-07 \\
(7.40 E-07)\end{array}$ \\
\hline$\Delta$ Resel & $\begin{array}{r}763.98^{*} \\
(288.12)\end{array}$ & $\begin{array}{r}441.57 \\
(278.24)\end{array}$ & $\begin{array}{r}639.07^{*} \\
(173.88)\end{array}$ & $\begin{array}{r}1.57 E+04^{* *} \\
(686.12)\end{array}$ \\
\hline$C V 1(-1)$ & $\begin{array}{r}-0.06^{* * *} \\
(0.04)\end{array}$ & $\begin{array}{r}-0.04^{* * *} \\
(0.02)\end{array}$ & $\begin{array}{r}-0.07^{*} \\
(0.03)\end{array}$ & $\begin{array}{l}-0.10 \\
(0.08)\end{array}$ \\
\hline$R^{2}$ & 0.16 & 0.15 & 0.18 & 0.28 \\
\hline $\begin{array}{l}\text { Estimates } \\
P(-1) \\
\text { Oil }(-1) \\
\text { Resel }(-1)\end{array}$ & $\begin{array}{r}f \text { the individua } \\
-0.06 \\
0.10 \\
6.66\end{array}$ & components in & $1(-1)$ & \\
\hline
\end{tabular}

Note: $9601-0416$ refers to the period week 1,1996 , to week 16,2004 , etc. ${ }^{*}$ Significant at the $1 \%$ level, ** significant at the $5 \%$ level, *** significant at the $10 \%$ level. 